\title{
Evaluation of the Quality of Formulations Containing Lactase ( $\beta$-galactosidase) Employing Gel Electrophoresis and Cell Phone
}

\author{
Bruna Soares Dionizio1, Diego Victor Babos², Dulce Helena Ferreira de Souza1 (iD, Edenir \\ Rodrigues Pereira-Filho $\bowtie$ (iD
}

${ }^{1}$ Laboratório de Bioquímica Funcional e Estrutural, Departamento de Química, Universidade Federal de São

Carlos - P. O. Box 676, São Carlos, SP, 13565-905, Brazil

${ }^{2}$ Grupo de Análise Instrumental Aplicada, Departamento de Química, Universidade Federal de São Carlos

P. O. Box 676, São Carlos, SP, 13565-905, Brazil

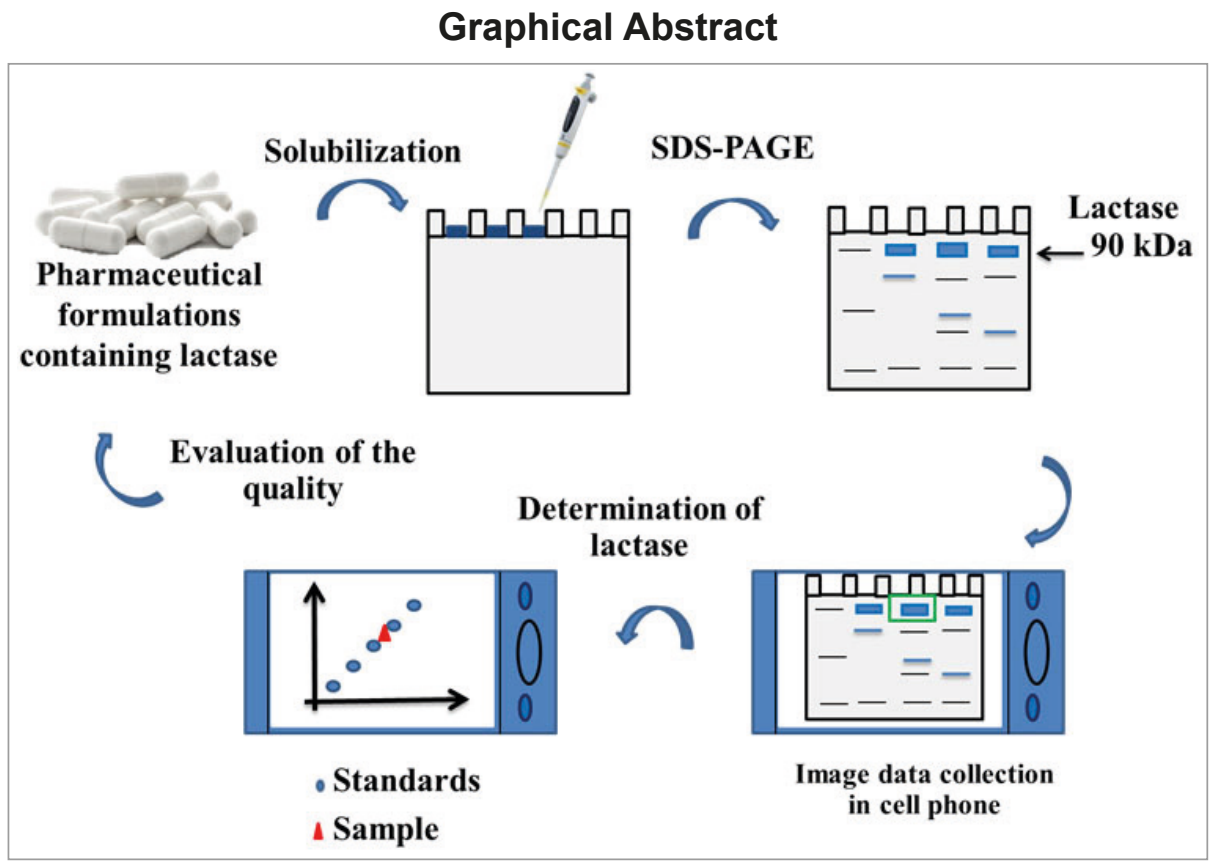

A quantification method of the lactase enzyme in pharmaceutical formulations is proposed employing digital images obtained from a cell phone camera and processed using the colorimetric application. The use of sodium dodecyl sulfate polyacrylamide gel electrophoresis (SDS-PAGE) made it possible to identify the lactase enzyme, to fractionate possible protein impurities and to evaluate the degradation of lactase present in the analyzed formulations. In addition, gel electrophoresis made it possible to determine lactase free of matrix interference. The proposed method presented limit of quantification of $0.002 \mathrm{mg}$ lactase (0.03 FCC), using external calibration. Recoveries of lactase added to the samples were in the range $78-104 \%$. The concentrations found in different pharmaceutical formulations samples containing lactose were in the range $7-621 \mathrm{mg}$ (104-9319 FCC). The relative standard deviations (RSD) were in the range of $3-13 \%$. Of the six samples analyzed, only two (\#S2 and \#S5) were in agreement with the sample label description.

Keywords: lactase, digital image, PhotoMetrix, lactose intolerance, gel electrophoresis 


\section{INTRODUCTION}

Lactase ( $\beta$-galactosidase, Enzyme Commission number 3.2.1.23) belongs to the class of hydrolytic enzymes which catalyze the conversion of lactose to glucose and galactose [1]. Several people cannot or inefficiently metabolize lactose, developing lactose intolerance. This syndrome affects approximately $70 \%$ of the world's population, mainly American Indians and Asians [2,3].

The main symptoms resulting from lactose intolerance are gastrointestinal clinical manifestations, such as abdominal distension and pain, diarrhea, nausea, flatulence and abdominal discomfort $[3,4]$. Thus, the food and pharmaceutical industries are very interested in the production of the lactase enzyme, since it can be used in the production of lactose free food, such as milk and dairy products, and also as a food supplement, used to prevent unwanted symptoms caused by intolerance to lactose.

Lactase is usually industrially produced, using the fungi Aspergillus niger, Aspergillus oryzae, Kluyveromyces lactis and Kluyveromyces marxianus, because they can have acceptable productivities and yields of lactase. However, lactase can also be obtained by different microorganisms such as bacteria and yeasts $[1,5,6]$.

Pharmaceutical formulations containing lactase are classified as food supplements according to the Food and Drugs Administration (FDA), so can be submitted to quality, efficacy and stability testing $[7,8]$. Thus, it is possible that some commercially available formulations may contain irregularities as to their content and enzymatic activity. The pharmaceutical formulations express the lactase content in lactase FCC unit (FCC - Food Chemical Codex Units), and are usually in the range from 3,000 to 10,000 FCC [9].

The lactase-containing formulations present some limitations, since it is reported in the literature that the enzyme has low physicochemical stability and reduced shelf life, although many technologies are proposed to overcome these drawbacks $[4,10]$. Its exposure to drastic conditions such as extremes $\mathrm{pH}$ and temperature can lead to enzymatic inactivation due to the formation of insoluble particles and aggregates, as well as protein unfolding and degradation [11,12]. Thus, it is important to monitor these products for the quality control and efficacy of commercially available supplements containing lactase.

Analytical methods for the determination of proteins usually require sample preparation and quantification. The most used methods for the determination of proteins employ molecular absorption spectrophotometry in the UV-Vis region (for example Bradford method) [13,14], liquid chromatography coupled with mass spectrometer [15,16,17], electrochemical methods [18], densitometry [19,20], fluorescence spectroscopy [21], among others. These techniques present certain difficulties in their implementation, such as lack of selectivity, sensitivity, and possible matrix effects.

The polyacrylamide gel electrophoresis (PAGE) or Agarose gels are widely used in microbiological assays for separation and identification of proteins and DNA, respectively; besides being simple, effective and low-cost methods. SDS-PAGE processing method consists in the separation of proteins under denaturing sodium dodecyl sulfate (SDS), reducing with $\beta$-mercaptoethanol or even heating conditions. The proteins are heated with SDS before electrophoresis so the charge-density of all is made roughly equal. Consequently, when these samples undergo electrophoresis, proteins separate according to their molecular mass [22-25].

The development of methods employing colorimetric detection with unusual devices as cell phones, digital cameras, computers, scanners, webcams, among others is a reality that is increasingly arousing the interest of the scientific community [26-32]. Simplicity in the acquisition of analytical signals (image), and the possibility to perform the data processing in the device is one of the great advantages of employment $[27,28,33,34]$.

In this context, the goal of this study is to develop a procedure for the analysis of pharmaceutical formulations containing lactase, using gel electrophoresis as a method of protein fractionation and processing digital images, obtained from a cell phone through the application PhotoMetrix. In addition, the proposed analytical method could be implemented as a quality control tool in pharmaceutical formulations containing lactase, being an affordable and inexpensive alternative. 


\section{MATERIALS AND METHODS Instrumentation}

Bio-Rad Mini-Protean ${ }^{\circledR}$ Tetra system (Biorad, California, USA) were employing for the SDS-PAGE electrophoresis. The system can operate up $500 \mathrm{~W}$ and $600 \mathrm{~V}$.

The image data were captured by the camera of a cell phone SM-J500M Samsung (Samsung, Seoul, South Korea), camera with 13 MP (megapixels), 5 MP frontal (flash frontal LED). The image data were processed using PhotoMetrix software, freely available in http://www.photometrix.com.br/ [35].

\section{Reagents, Analytical Solutions and Samples}

All solutions were prepared using high purity water $\left(18.2 \mathrm{M} \Omega \mathrm{cm}\right.$ resistivity) obtained from a Milli- $\mathrm{Q}^{\circledR}$ Plus Total Water System (Millipore Corp., Bedford, MA, USA). All glassware and polypropylene vessels were decontaminated prior to use by detergent washing and then thorough rinsing with distilleddeionized water.

Lactase 15,000 FCC g-1 (Fagron, São Paulo, Brazil) was used to prepare standard solutions for calibration curve and addition recovery test. Each $1 \mathrm{~g}$ of the lactase standard is equivalent to approximately 15,000 lactase units FCC.

The sample buffer was prepared with Tris- $\mathrm{HCl} 0.188 \mathrm{~mol} \mathrm{~L}-1, \mathrm{pH} 6.8$ (tris(hydroxymethyl) aminomethane, $\geq 99.0 \%$, Sigma-Aldrich, St. Louis, USA), glycerol 30\% v/v $(\geq 99.0 \%$, Sigma-Aldrich, St. Louis, USA), $\beta$-mercaptoethanol 15\% v/v (98.0\%, Sigma-Aldrich), Sodium dodecyl sulfate - SDS $6 \% \mathrm{w} / \mathrm{v}\left(\mathrm{C}_{12} \mathrm{H}_{25} \mathrm{NaO}_{4} \mathrm{~S}, \geq 98.5 \%\right.$, Sigma-Aldrich), and bromophenol blue $0.01 \% \mathrm{w} / \mathrm{v}\left(\mathrm{C}_{19} \mathrm{H}_{10} \mathrm{Br}_{4} \mathrm{O}_{5} \mathrm{~S}, \geq\right.$ 99.0\%, J.T. BAKER, Phillipsburg, USA).

The protein molecular weight standard employed was in the range of $116-14.4 \mathrm{kDa}$ (Thermo Scientific, Lithuania).

The SDS-PAGE were composed of two parts called concentrator or stacking gel (upper gel, $\mathrm{pH} 6.8$ ) and gel separator or running (lower gel, $\mathrm{pH}$ 8.8). These gels were prepared using bis-acrylamide (bis (N,N'-Methylene-bis-acrylamide) $0.8 \% \mathrm{w} / \mathrm{v}$, Bio-Rad and acrylamide 30\% w/v, $\geq 99.0 \%$, Sigma-Aldrich), Tris- $\mathrm{HCl}$, ammonium persulphate $10 \% \mathrm{w} / \mathrm{v}\left(\left(\mathrm{NH}_{4}\right)_{2} \mathrm{~S}_{2} \mathrm{O}_{8}, \geq 99.0 \%\right.$, Synth, Diadema, Brazil), Sodium dodecyl sulfate - SDS $10 \% \mathrm{w} / \mathrm{v}\left(\mathrm{C}_{12} \mathrm{H}_{25} \mathrm{NaO}_{4} \mathrm{~S}, \geq 98.5 \%\right.$, Sigma-Aldrich) and TEMED ${ }^{\circledR}\left(\mathrm{N}, \mathrm{N}^{\prime}, \mathrm{N}^{\prime}, \mathrm{N}^{\prime}-\right.$ tetramethylethyl-enediamine, 99.0\%, Sigma-Aldrich) [22].

The SDS-PAGE buffer Tris Base $25 \mathrm{mmol} \mathrm{L}^{-1}$, Glycine $192 \mathrm{mmol} \mathrm{L}^{-1},\left(\mathrm{C}_{2} \mathrm{H}_{5} \mathrm{NO}_{2}, \geq 99.0 \%\right.$, SigmaAldrich) and SDS $0.1 \% \mathrm{w} / \mathrm{v}$, was prepared for running the gel [22].

The solution used for staining the gel was Coomassie Brilliant Blue R $2500.15 \% \mathrm{w} / \mathrm{v}\left(\mathrm{C}_{45} \mathrm{H}_{44} \mathrm{~N}_{3} \mathrm{O}_{7} \mathrm{~S}_{2} \mathrm{Na}\right.$, Sigma-Aldrich), methanol 50\% v/v ( $\mathrm{CH}_{4} \mathrm{O}, \geq 99.8 \%$, Synth), and acetic acid $10 \% \mathrm{v} / \mathrm{v}\left(\mathrm{C}_{2} \mathrm{H}_{4} \mathrm{O}_{2}, \geq 99.7 \%\right.$, Synth). The gel was discolored by diffusion in a solution of acetic acid $7 \% \mathrm{v} / \mathrm{v}$.

Six samples of pharmaceutical formulations of lactase were analyzed using the proposed method. These samples were donated by patients from São Carlos city (São Paulo, Brazil), who use these supplements daily to control lactose intolerance.

\section{Analytical Procedure}

Sample and Standards Preparation

The tablets of samples containing lactase were homogenized in mortar and pistil. Subsequently, approximated $50 \mathrm{mg}$ of the sample were transferred to a flask and solubilized in $10 \mathrm{~mL}$ high purity water. The solutions obtained were refrigerated at $4{ }^{\circ} \mathrm{C}$ until analysis. Before the analysis, the samples were mixed with the buffer in the proportion of 3:1 (sample:sample buffer), and heated to $100{ }^{\circ} \mathrm{C}$ in a dry bath for $5 \mathrm{~min}$, for denaturation.

A standard solution containing $10 \mathrm{mg} \mathrm{mL}^{-1}$ lactase (150 FCC mL-1 lactase) was prepared using 100 $\mathrm{mg}$ lactase solubilized in $10 \mathrm{~mL}$ high purity water. Aliquot of standard solution was diluted in sample buffer at the ratio 3:1 (80 $\mu \mathrm{L}$ standard solution:26.6 $\mu \mathrm{L}$ sample buffer) resulting in a $7.5 \mathrm{mg} \mathrm{mL}^{-1}$ lactase solution which was heated to $100^{\circ} \mathrm{C}$ in a dry bath for $5 \mathrm{~min}$, for denaturation and analysis. The standard 
curve was prepared with aliquots of this solution, in the $0-0.38 \mathrm{mg}$ lactase range. The first standard solution of the calibration curve, corresponding to a concentration of $0 \mathrm{mg}$, refers to the blank.

\section{Gel Preparation}

The comb was carefully removed from the gel, wells were rinsed with deionized water and the gel mounted in the apparatus Bio-Rad Mini-Protean ${ }^{\circledR}$ Tetra system. The SDS-PAGE buffer was added to the bottom and the top reservoirs. Samples aliquots were placed in the bottom of the wells in the sampling the gel using pipette. For qualitative analysis and verification of impurities in the pharmaceutical formulations containing lactase, $20 \mu \mathrm{L}$ of all samples were placed in the bottom of wells of sampling the gel. For quantitative analysis, aliquots of $10 \mu \mathrm{L}$ of the samples \#S1, \#S2 and \#S3, and $5 \mu \mathrm{L}$ of the samples \#S4, \#S5 and \#S6, were employed.

Different aliquots $(2.5,5,10,15,20,30,40$ and $50 \mu \mathrm{L})$ of a standard solution containing $7.5 \mathrm{mg} \mathrm{mL}^{-1}$ lactase were used as standards for analytical curve.

For to stack all the samples on the gel were used $80 \mathrm{~V}$. The run was carried out at $120 \mathrm{~V}$ for $120 \mathrm{~min}$ until the bromophenol blue had reached the lower edges of the gel.

\section{Staining the Gel with Coomassie Blue}

The gel was stained with solution of coomassie blue $0.15 \% \mathrm{w} / \mathrm{v}$ for $5 \mathrm{~min}$ and under stirring. The gels were destained by diffusion a solution of acetic acid $7 \% \mathrm{v} / \mathrm{v}$ for $12 \mathrm{~h}$. The blue staining remains only in the protein bands because this is the result of the reaction between the sulfonic groups of the dye and the amine groups of the proteins.

\section{Image Data Collection and Quantification of Lactase by Colorimetry on Cell Phone Devices}

After the discoloration of the gels, samples and standard images were acquired using PhotoMetrix software, according to Figure 1 . The images $(n=5)$ for the lactase protein band on the $90 \mathrm{kDa}$ gel were focused using the camera of the cell, at a distance of $18 \mathrm{~cm}$, and acquired using a 32x32 pixel spot. The camera flash and $640 \times 480$ pixels resolution were used.

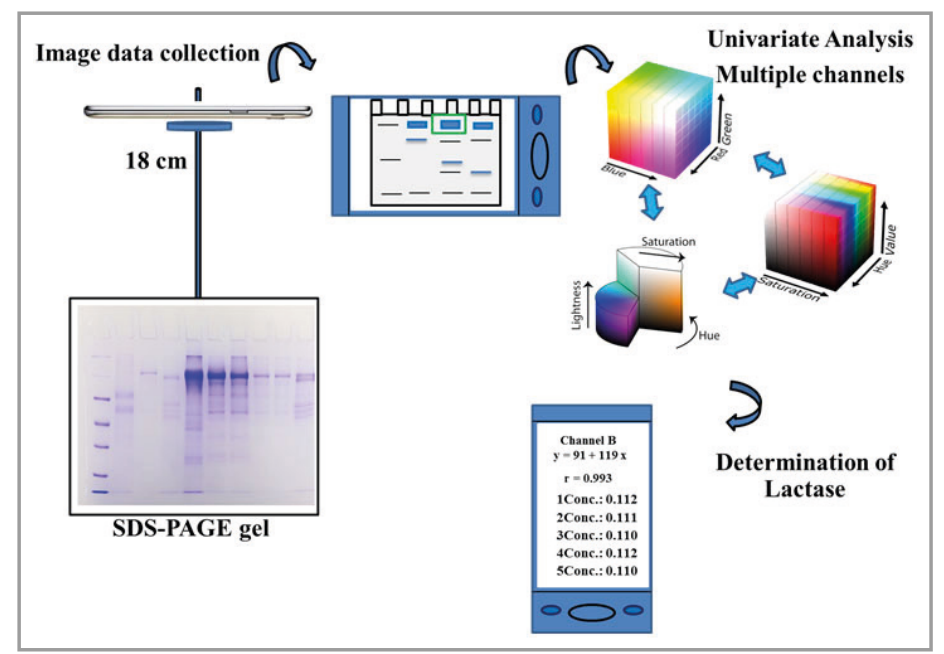

Figure 1. Acquisition of image data for determination of lactase by proposed method.

Univariate calibration employing multichannel red $(R)$, green $(G)$, blue $(B)$, hue $(H)$, intensity $(I)$, value $(V)$, saturation $(S)$ and lightness $(L)$ was evaluated for the quantification of lactase. The best calibration obtained, with a better linear correlation coefficient and better trueness obtained from the 
addition/recovery tests, was chosen for the quantification of lactase in commercial formulations.

\section{Figures of Merit}

The limits of detection (LOD) and quantification (LOQ) of the method proposed were calculated according to IUPAC recommendations: $3 \times \mathrm{SD}_{\text {blank }} / \mathrm{b}(\mathrm{LOD})$, and $10 \times \mathrm{SD}_{\text {blank }} / \mathrm{b}(\mathrm{LOQ})$, where $S D$ is the standard deviation for ten blank measurements (using bleached electrophoresis gel with coomassie blue) and $b$ is the angular coefficient of the calibration curve [36].

\section{Addition / Recovery Tests}

Accuracy of the proposed method was also evaluated by means of addition / recovery tests. A spike with $0.113 \mathrm{mg}$ lactase was added in all samples analyzed. The trueness was calculated from equation 1 :

$$
\text { Trueness }=\frac{j \times 100}{j_{\text {ref }}} \quad \text { Eq. } 1
$$

where $j$ is the mass determined by the proposed method and $j_{\text {ref }}$ is the reference mass of the lactase added (spike).

\section{RESULTS AND DISCUSSION}

\section{Evaluation of Impurities and Degradation in Formulations Containing Lactase Employing SDS- PAGE}

Different microorganisms (fungi, bacteria and yeasts) and industrial purifications routes can be used to obtain lactases that may present significant differences in their structures and physicochemical properties resulting from different mechanisms of production. For example, lactase from Aspergillus oryzae is a monomeric enzyme having a molecular mass of $90 \mathrm{kDa}$, does not require cofactors and has an optimal action $\mathrm{pH}$ of 4.5 [10]; but the lactase from Lactobacillus acidophilus has a molecular mass of $540 \mathrm{kDa}$, needs magnesium as cofactor and presents a optimum $\mathrm{pH}$ in 6.2-6.6 [37].

All samples analyzed in this study state in their labels that the lactase used in the formulations originated from the fungus $A$. oryzae. The lactase produced by this fungus requires relatively inexpensive industrial procedures, but they are more unstable enzymes $[11,12,38]$. To analyze the purity of the lactase in the formulations, electrophoresis was used in denaturing gel (SDS-PAGE) (Figure 2).

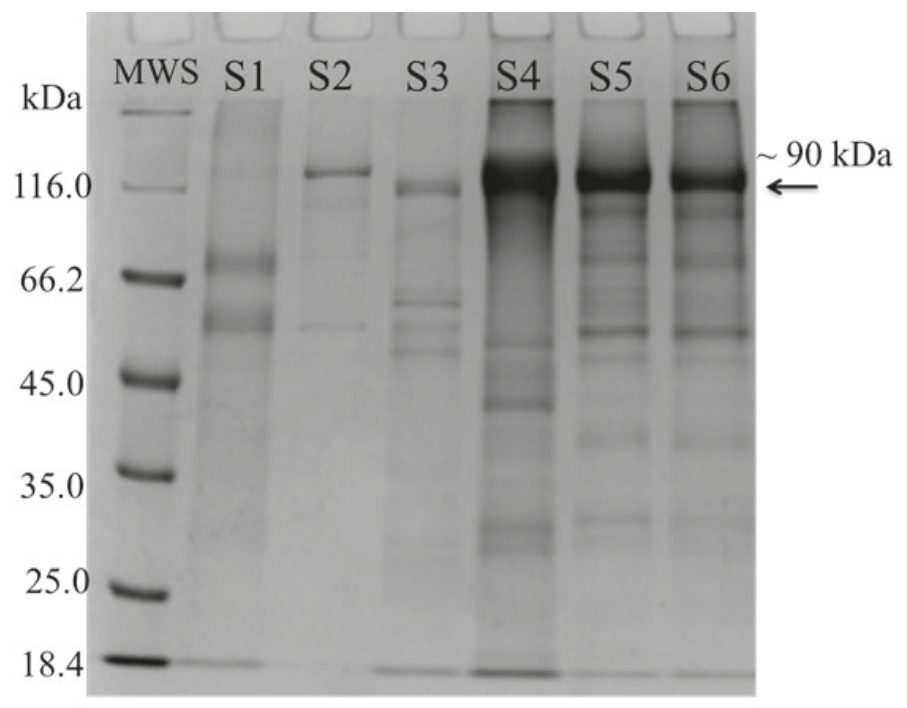

Figure 2. Evaluation of impurities and possible degradation of lactase in pharmaceuticals formulations by SDS-PAGE. Molecular Weight Standard (MWS) and Sample (S). 
It is possible to observe in the gel different protein bands, ranging from 18 to $116 \mathrm{kDa}$, thus indicating that the formulations do not present only the lactase, as expected. The various bands observed on the gel demonstrate that different proteins are present, even after purification steps employed in obtaining lactase.

Samples \#S3, \#S4, \#S5 and \#S6 show an intense band at about $90 \mathrm{kDa}$, molecular mass expected for lactase from $A$. oryzae, being in agreement with the descriptions on the labels. Sample \#S2, although slightly above $90 \mathrm{kDa}$, also can be inferred to lactase from $A$. oryzae. This difference may be related to the mode of expression of the protein, since the manufacturers do not give details of how these proteins were expressed and purified. If the proteins are recombinant, these can be expressed fused with tags like GST (Glutathione S-transferase), MPB (Maltose-binding protein), His-Tag (Poly-histidine-tagged) $[1,6,39]$, among others and thus the proteins may have molecular mass just above $90 \mathrm{kDa}$.

However, the sample \#S1 showed two strong protein bands in the range of 50 to $70 \mathrm{kDa}$. This may indicate the degradation of the enzyme lactase in this analyzed formulation, since a protein band around $90 \mathrm{kDa}$ was expected, molecular weight of the lactase expressed by $A$. oryzae.

The instability and enzymatic degradation of lactase can be due to several factors as inadequate exposure of the formulations, by the users and or manufacturers, high temperature that can lead to the enzymatic inactivation due to the formation of insoluble particles and aggregates, besides unfolding and protein degradation [4,10-12]. Therefore, these factors may justify what was observed in the analysis of sample \#S1.

\section{Figures of Merit}

The main analytical performance parameters (linear range, linear correlation coefficient, LOD, LOQ and precision) calculated for the method proposed are shown in Table I. Among the eight evaluated channels (R, G, B, H, I, V, S and L channel) in the univariate mode, the best calibration curve was obtained using the channel B (blue) with a linear correlation coefficient 0.993 , for this reason it was used for lactase determinations, Figure 3 . The precision $(n=5)$ was calculated using all samples and RSD varied from 3 to $13 \%$. Overall, the values obtained were considered satisfactory for further development of the analytical methods for determination of lactase in pharmaceuticals formulations employing colorimetry and mobile device.

Table I. Parameters of analytical performance for the determination of lactase employing colorimetric on mobile devices proposed method

\begin{tabular}{lc}
\hline Parameters & Found \\
\hline Channel & B (blue) \\
Linearity range (mg/FCC) & $0-0.38 / 0-5.6$ \\
Calibration curve equation (linear model) & $y=119.82 x+91.67$ \\
Linear correlation coefficient (R) & 0.993 \\
Limit of detection (mg/FCC) & $0.0006 / 0.009$ \\
Limit of quantification (mg/FCC) & $0.002 / 0.03$ \\
RSD (\%) & $3-13$ \\
\hline
\end{tabular}




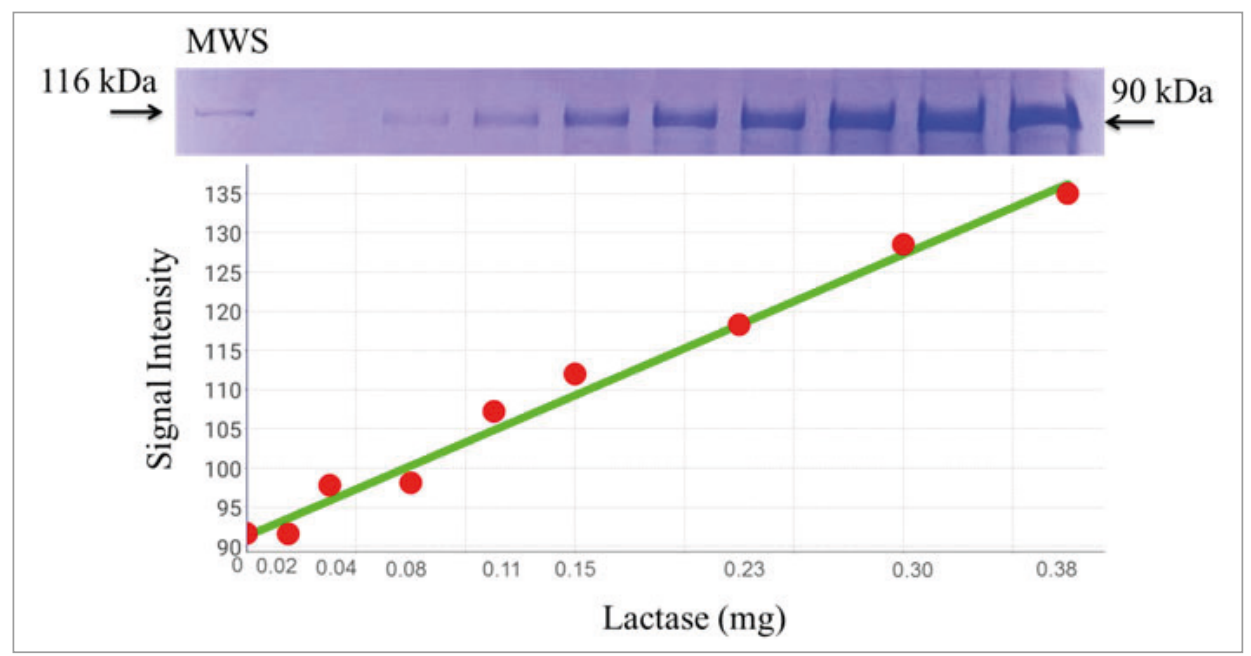

Figure 3. Fragmented chromatograms of different mass $(0-0.38 \mathrm{mg})$ of standard lactase $(90 \mathrm{kDa})$ on gel electrophoresis along with molecular weight marker proteins and calibration curve for lactase.

The LOD value calculated for the method proposed in the determination of $\beta$-galactosidase (LOD $=0.6 \mu \mathrm{g}$ ), was similar to the values reported in the study developed by Jesus et al. (2019) [26] for the quantification of the albumin ( $\mathrm{LOD}=0.6 \mu \mathrm{g}$ ), trypsin inhibitor (LOD $=0.7 \mu \mathrm{g}$ ) and carbonic anhydrase $(\mathrm{LOD}=0.7 \mu \mathrm{g})$ proteins in human serum sample, both using SDS-PAGE and PhotoMetrix. These values demonstrate the potential of using these tools in the proteomics field.

\section{Addition / Recovery Tests}

Further tests were performed to verify the accuracy of the analytical method developed for the determination of the lactase. The tests were made for all lactase samples analyzed spiked with 0.113 mg enzyme. The trueness of lactase added to the samples varied within the range $78-104 \%$ (Table II), demonstrating the accuracy in the measurements for all samples.

\section{Determination of Lactase in Pharmaceutical Formulations}

The proposed method was applied in the analysis of six formulations containing lactase in the range 4,000-10,000 FCC, and the results are shown in Table II. The measured values were in the range 7-621 mg lactase or 104-9319 FCC. The specifications of most tested pharmaceutical formulations samples were not consistent with the information described on the labels. The determined values for the lactase are not in agreement with the label specifications of formulations \#S1, \#S3, \#S4 and \#S6. Only formulations \#S2 (3875 \pm 168 FCC) and \#S5 (9319 \pm 316 FCC) are in concordance with the information described on the labels (\#S2 - 4,000 FCC and \#S5 - 10,000 FCC).

The lack of agreement of the lactase values described in the commercial formulations with those determined by the proposed method may be associated with several factors mentioned above, but mainly protein degradation. 
Table II. Determination of lactase (mean \pm standard deviation, $n=5$ ) in commercial pharmaceutical formulations by proposed method. Trueness (\%) of lactase compared to sample label description and spiked, for all samples.

\begin{tabular}{|c|c|c|c|c|c|}
\hline \multirow{2}{*}{ Sample } & \multirow{2}{*}{$\begin{array}{l}\text { Sample label } \\
\text { description } \\
\text { (FCC) }\end{array}$} & \multicolumn{2}{|c|}{ Method proposed } & \multirow{2}{*}{ Trueness (\%) } & \multirow{2}{*}{$\begin{array}{c}\begin{array}{c}\text { Addition I } \\
\text { recovery test }\end{array} \\
\text { Trueness (\%) }\end{array}$} \\
\hline & & FCC & mg & & \\
\hline $\mathrm{S} 1$ & 4000 & $104 \pm 3$ & $7 \pm 0.23$ & 3 & 104 \\
\hline S2 & 4000 & $3875 \pm 168$ & $258 \pm 11$ & 97 & 97 \\
\hline S3 & 4500 & $1692 \pm 227$ & $113 \pm 15$ & 38 & 78 \\
\hline S4 & 9000 & $5140 \pm 319$ & $343 \pm 21$ & 57 & 94 \\
\hline S5 & 10000 & $9319 \pm 316$ & $621 \pm 21$ & 93 & 81 \\
\hline S6 & 10000 & $7635 \pm 187$ & $509 \pm 11$ & 76 & 78 \\
\hline
\end{tabular}

In this way the proposed method proves to be an excellent tool to evaluate the quality of the commercial formulations containing lactase, using a method that employs as the analytical technique a mobile device - cell phone. The use of SDS-PAGE and the processing of the digital images acquired with the camera of cell phone by PhotoMetrix software, allow to quantify proteins with sensitivity (microgram levels), accuracy and precision satisfactory. A difficulty encountered in the development of this method was in the acquisition of the calibration standard for $\beta$-galactosidase enzyme with adequate specifications (e.g. purity) to be employed.

\section{CONCLUSIONS}

The proposed method based on colorimetric devices and electrophoresis was effective for the determination of lactase in different supplements containing this enzyme. The electrophoresis under denaturing conditions allowed to identify the lactase-related band and the separation of the analyte from possible interferences present in the sample matrix. SDS-PAGE proved to be an excellent analytical tool in the identification of protein impurities and making possible the determination of the concentration of lactase in the formulations using the mobile application. The use of digital images obtained by a cell camera together with the use of Photometrix software, allowed to develop a simple and inexpensive method for determination of lactase. The analytical method should be useful as a tool for assessing the quality of supplements marketed containing lactase, since the monitoring of the enzyme in these formulations may contribute to the efficacy of the supplements consumed.

Manuscript submitted: April 18, 2019; revised manuscript submitted: July 8, 2019; manuscript accepted: August 8, 2019; published online: September 27, 2019.

\section{REFERENCES}

1. Katrolia, P.; Yan, Q.; Jia, H.; Li, Y.; Jiang, Z.; Song, C. J Mol Catal B Enzym., 2011, 69, pp 112-119.

2. Leonardi, M.; Gerbault, P.; Thomas, M. G.; Burger, J. Int Dairy J., 2012, 22, pp 88-97.

3. Swagerty, D. L. Jr.; Walling, A. D.; Klein, R. M. Am Fam Physician., 2002, 65, pp 1845-1850.

4. Traffano-Schiffo, M. V.; Castro-Giraldez, M.; Fito, P. J.; Santagapita, P. R. Food Res Int., 2017, 100, pp 296-303.

5. Khaled, B.; Fethia, F. N.; Kemal, G.; Matpan, B. F.; Omer, A.; Amina, H. Res J Biotechnol., 2016, 11, pp 40-48. 
6. Ren, Z. Y.; Liu, G. L.; Chi, Z.; Han, Y. Z.; Hu, Z.; Chi, Z. M. Process Biochem., 2017, 61, pp 38-46.

7. Blendon, R. J.; DesRoches, C. M.; Benson, J. M.; Brodie, M.; Altman, D. E. Arch Intern Med., 2001, 161, pp 805-810.

8. https://www.fda.gov/consumers/consumer-updates/fda-101-dietary-supplements [Assessed on 27 August, 2019].

9. https://efsa.onlinelibrary.wiley.com/doi/epdf/10.2903/j.efsa.2009.1236 [Assessed on 22 April, 2018].

10. Gennari, A.; Mobayed, F. H.; Volpato, G.; de Souza, C. F. V. Int J Biol Macromol., 2018, 109, pp 303-310.

11. Nichele, V.; Signoretto, M.; Ghedini, E. J Mol Catal B Enzym., 2011, 71, pp 10-15.

12. Ohtake, S.; Kita, Y.; Arakawa, T. Adv Drug Deliv Rev., 2011, 63, pp 1053-1073.

13. Ku, H. K.; Lim, H. M.; Oh, K. H.; Yang, H. J.; Jeong, J. S.; Kim, S. K. Anal Biochem., 2013, 434, pp 178-180.

14. Zhang, K.; Cai, R.; Chen, D.; Mao, L.; Anal Chim Acta., 2000, 413, pp 109-113.

15. Halvorsen, T. G.; Reubsaet, L. Trends Analyt Chem., 2017, 95, pp 132-139.

16. Vilà-Rico, M.; Colomé-Calls, N.; Martín-Castel, L.; Gay, M.; Azorín, S.; Vilaseca, M.; Planas, A.; Canals, F. J Proteom., 2015, 127, pp 234-246.

17. Magri, A.; Soler, M. F.; Lopes, A. M.; Cilli, E. M.; Barber, P. S.; Pessoa-Junior, A.; Perreira, J. F. B. Anal Bioanal Chem., 2018, 410, pp 6985-6990.

18. Shahmiri, M. R.; Bahari, A.; Karimi-Maleh, H.; Hosseinzadeh, R.; Mirnia, N. Sens Actuators B Chem., 2013, 177, pp 70-77.

19. Muharram, M. M.; Abdel-Kader, M. S. Saudi Pharm J., 2017, 25, pp 359-364.

20. Ahmadifar, S.; Le, T. C.; Marcocci, L.; Pietrangeli, P.; Mateescu, M. A. Anal Chim Acta., 2017, 975, pp 78-85.

21. Wang, K.; Donnarumma, F.; Baldone, M. D.; Murray, K. K. Anal Chim Acta., 2018, 1027, pp 41-46.

22. Laemmli, U. K. Nature 1970, 227, pp 680-685.

23. Reddy, P. R.; Raju, N. Gel-electrophoresis and its applications. In: Magdeldin, S. (Ed.). Gel Electrophoresis - Principles and Basics. Rijeka: InTech. 2012.

24. Sim, J. Z.; Nguyen, P. V.; Lee, H. K.; Gan, S. K. E. Nat. Methods Appl Not., 2015, pp 1-2.

25. Nguyen, P. V.; Ghezal, A.; Hsueh, Y.; Boudier, T.; Gan, S. K.; Lee, H. K. Electrophoresis, 2016, 37, pp 2208-2216.

26. Jesus, J. R.; Guimarães, I. C.; Arruda, M. A. Z. J Proteom., 2019, 198, pp 45-49.

27. Grudpan, K.; Kolev, S. D.; Lapanantnopakhun, S.; McKelvie, I. D.; Wongwilai, W. Talanta, 2015, 136, pp 84-94.

28. Kwon, L.; Long, K. D.; Wanc, Y.; Yua, H.; Cunninghama, B. T. Biotechnol Adv., 2016, 34, pp 291304.

29. Wang, H.; Sun, Y.; Yue, W.; Kang, Q.; Li, H.; Shen, D. Analyst, 2018, 143, pp 1670-1678.

30. Bao, X.; Jiang, S.; Wang, Y.; Yu, M.; Han, J. Analyst, 2018, 143, pp 1387-1395.

31. Malhotra, K.; Noor, M. O.; Krull, U. J. Analyst, 2018, 143, pp 3049-3058.

32. Morbioli, G. G.; Mazzu-Nascimento, T.; Stockton, A. M.; Carrilho, E. Anal Chim Acta., 2017, 970, pp 1-22.

33. Helfer, G. A.; Magnus, V. S.; Böck, F. C.; Teichmann, A.; Ferrão, M. F.; da Costa, A. B. J Braz Chem Soc., 2017, 28, pp 328-335.

34. Shen, H.; Khan, R.; Wang, X.; Li, Z.; Qu, F. Anal Bioanal Chem., 2018, 410, pp 7177-7183.

35. http://www. photometrix.com.br [Assessed on 10 February, 2018].

36. Currie, L. A.; Anal Chim Acta, 1999, 391, pp 105-126.

37. Harju, M.; Kallioinen, H.; Tossavainen, O. Int Dairy J., 2012, 22, pp 104-109.

38. Yang, S.; Okos, M. R. O. Biotechnol Bioeng., 1989, 33, pp 873-885.

39. Paraskevopoulou, V.; Falcone, F. H. Microorganisms, 2018, 6, pp 47-63. 